\title{
LIGHT RELATIONS IN A PLUM ORCHARD TRELLISED HORIZONTALLY IN COMPARISON WITH STANDARD, CENTRAL LEADER TRAINING
}

\author{
Augustyn MIKA, Zbigniew BULER* \\ Research Institute of Horticulture \\ Konstytucji 3 Maja 1/3 str., 96-100 Skierniewice, Poland \\ Received: April 2016; Accepted: October 2016
}

\begin{abstract}
Plum trees of 'Elena', designed for mechanical harvesting with a straddle self-propelled harvester, were planted in 2008 in the experimental orchard at Dąbrowice at a distance of $4 \times 1.5$ and $2.0 \mathrm{~m}$. The trees were trained to a central leader to a height of $2.7 \mathrm{~m}$ and 1.5 or $2.0 \mathrm{~m}$ spread. Plum trees designed for mechanical harvesting with a small tractor-driven harvester were spaced at $4 \times 1.0$ or $1.5 \mathrm{~m}$ and were trellised horizontally on wires stretched along rows $0.8 \mathrm{~m}$ above the ground. Fruits were harvested in 2012 2015. The cumulative yield from the trellised trees was only half of that from the trees trained to a central leader, whereas the fruit load index (weight of fruits per $\mathrm{m}^{3}$ canopy) was the highest at $4 \times 1.0 \mathrm{~m}$ ). To explain this phenomenon, studies were conducted in 2015 on light relations in the two training systems. The studies revealed that light transmission has different patterns in the two training systems, but the level of light interception was nearly similar. Light distribution was more beneficial for photosynthesis in the central leader trees. The trees trained to a horizontal canopy had poor illumination at the canopy base. The main reason of low productivity of the horizontal canopy was low canopy volume.
\end{abstract}

Key words: Prunus oeconomica Borkh., training systems, mechanical harvesting, light interception and distribution

\section{INTRODUCTION}

Fruits of plums and tart cherries grown for processing could be presently harvested with a straddle combine harvester working in continuous motion. For this harvesting technology, trees should be spaced $4.0 \mathrm{~m}$ between rows and $1.5-2.0 \mathrm{~m}$ in the row according to tree vigor. Trees should be trained to the standard, central leader form, with a conical shape, to a height of $2.7 \mathrm{~m}$ and a spread of $2.0 \mathrm{~m}$ (Mika et al. 2015). On the other hand, soft fruits designed for dessert purposes could be mechanically harvested from trees spaced at $4 \times 1.0-1.5 \mathrm{~m}$, trellised on wires to a horizontal canopy (table form). In such a canopy, trees in the row are trained to a continuous plane $2.0 \mathrm{~m}$ wide, $1.5 \mathrm{~m}$ in vertical dimension, and unlimited length of the row. In this harvesting technology, the harvester driven by a tractor moves in the alleyway between the tree rows, while its working unit gently shakes the fruit down into the transporter below the canopies. Fruits are only slightly exposed to bruising because they have to travel a short distance when falling from the fruiting wood to the transporter.

Horizontal canopy system was developed in New Zealand by Dunn and Stolp (1981) as a useful for mechanical harvesting of apples by collecting fruits below fruit canopies instead from their inner and outer so-called "fruiting mantles." The idea was not spread because of the important changes in orchard organization in the meantime. Large apple trees were replaced with small dwarf trees making manual apple fruit picking easy and efficient. Manual harvesting of soft fruits, plums and cherries, is still tedious and very laborious. For this reason, the horizontal canopy seems to be a justified solution for mechanical harvesting of dessert plums. However, in our trial comparing two training systems 
conducted in 2008-2015, 'Elena' plum trees trellised to a horizontal canopy appeared to be significantly less productive compared to the central leader form with a conical shape (Mika et al. 2016). Preliminary observations suggested that the interception and distribution of sunlight within the trees trellised horizontally might be less efficient than in the central leader trees. For this reason, in 2015, we undertook a detailed investigation to determine light relations within the two training systems, that is, irradiation, distribution, transmission, and interception of incoming sunlight. Good sunlight penetration is the main factor influencing the productiveness of fruit trees. Orchard organization, such as planting density, row orientation, tree rectangularity, canopy shape, size, and height, play an important role in light interception, transmission, and distribution within the tree canopy (Palmer 1989; Mika et al. 2001; 2002; 2003). Experiments with artificial shading of apple trees revealed that reducing sunlight by $50 \%$ decreased the yield and red blush on fruit but reducing sunlight by $70 \%$ decreased fruit bud formation, fruit set, and yield (Jackson 1970). Plum trees trellised to a horizontal canopy have a lower volume than central leader trees and their canopies are more compact and more difficult to be penetrated by sunlight. The volume of horizontal canopy is limited in its vertical dimension to around $1.0 \mathrm{~m}$ because the shaking rods of the harvester are not able to work deeper. Jackson (1970) and Palmer (1989) presented an opinion that it is not the canopy volume that plays an important role in tree fruit productivity but the fruiting mantle, that is, the outer layer of tree canopy to a depth of $0.7 \mathrm{~m}$. The fruiting mantle should not be shaded.

Investigations by Wagenmakers (1995) indicated that the planting and training systems of fruit trees play the most important role in the interception and distribution of sunlight. Interception of more light can be achieved by increasing planting density, which can be combined with a more uniform light distribution and a higher light utilization. In a wellilluminated canopy, light interception increases when leaf density is high. A positive correlation between light interception and flower bud formation, fruit setting, and production of high-quality fruits has been reported by several authors (Palmer et al.
1992; Buler \& Mika 2009; Mika \& Buler 2015). Small trees planted at high density generally achieve greater light interception than do large trees at low densities (Palmer et al. 1992).

Most studies on the effects of orchard organization on sunlight distribution, transition, and interception have been conducted on apple plantations. Different productivities of plum trees in two different planting and training systems were the reason to study light relations in a plum orchard adapted to mechanical fruit harvesting in continuous motion.

\section{MATERIALS AND METHODS}

Plum trees of the Prunus oeconomica Borkh. 'Elena' grafted on Myrobalan rootstock (Prunus cerasifera var. divaricata Borkh.) were planted in the spring of 2008 at the experimental orchard of the Research Institute of Horticulture in Skierniewice, Poland (longitude $51^{\circ} 57^{\prime} \mathrm{N}$, latitude $20^{\circ} 08^{\prime} \mathrm{E}$, altitude $120 \mathrm{~m}$ ), on a sandy loam, deep soil with a $\mathrm{pH}$ of 5.5. The Skierniewice area is characterized by a Central European climate, with an annual rainfall of $507 \mathrm{~mm}$ and evapotranspiration of $489 \mathrm{~mm}$ during the growing season. The mean temperature of the coldest month of January is $3.1^{\circ} \mathrm{C}$, and the mean temperature of the warmest month of July is $18.1^{\circ} \mathrm{C}$.

The area of the experimental plot was 0.36 ha. Trees were planted in four $200 \mathrm{~m}$ long rows with a north-south orientation. In two rows, the trees were spaced at 1.0 and $1.5 \mathrm{~m}$ and trellised to a horizontal canopy according to Dunn and Stolp (1981) (Fig. 1). These trees were trained to harvest fruits with small tractor driven harvester. In order to train and support the canopy, concrete poles were driven into the ground to a depth of $0.8 \mathrm{~m}$ and a height of $1.2 \mathrm{~m}$ above the ground and spaced at $10 \mathrm{~m}$ intervals. Across the rows, metal bars (4 m long) were fixed to the poles at a height of $0.8 \mathrm{~m}$. Four wires were stretched along the row and fixed to the bars.

To obtain a horizontal canopy, the leader of each tree was cut off $1.0 \mathrm{~m}$ above the ground and the lateral shoots were bent and tied to the wires forming the first tier of branches. In the summertime, new shoots were similarly bent and tied. In the second and third year, gaps in the canopy were filled 
with new shoots. Toward the end of the third year, the trees formed an open texture and a well-spaced fruit-bearing horizontal surface, resembling a green roof. From the third year onward, the canopy was pruned twice a year, in the springtime and in July. Strong shoots were removed, and weak shoots preserved for fruiting.

In the other two rows, the trees spaced at 1.5 and $2.0 \mathrm{~m}$ were trained to the central leader form and served as the control for fruit picking by hand (Fig. 1). Here, after planting, the leaders of the control trees were lightly headed (to $1.7 \mathrm{~m}$ from the ground) and the lateral shoots were lightly pruned. Within 2 years, a conical shape was obtained, with a strong vertical leader and short horizontal branches. To keep the tree to the required height $(2.7 \mathrm{~m})$ and spread $(2.0 \mathrm{~m})$, renewal pruning was introduced from the third year onward. Old branches were removed and replaced with young shoots. The trees were pruned only in the springtime. Tree pollination was provided by two adjacent rows of plums 'Valjevka' and 'Common Prune'. The same trees also served as guard trees to ensure a uniform microclimate for the experimental trees. The trees were managed to the methods described by Mika et al. (2015).

\section{Tree growth, fruiting, and sunlight relation}

After planting, the growth of trees was measured by recording trunk circumference and the total summer shoot growth on 12 selected trees in each treatment. Trunk circumference converted to trunk cross-section area (TCSA), and total shoot growth in 2015 was recognized as the domain to compare the effects of light relations in two types of orchards. Fruit load $\left(\mathrm{kg} \cdot \mathrm{m}^{-3}\right.$ of canopy) and productivity indices were calculated.

In 2015, studies were conducted on light transmission, interception, and distribution in two training systems to find the reason why horizontal canopies were less productive than leader trees (Mika et al. 2016). For this purpose, eight uniform trees from among the trees trellised horizontally and the same number from among the trees trained to a leader canopy were selected. The selected trees were spaced at $4 \times 1.5 \mathrm{~m}$. Horizontal canopy was trellised at $0.8 \mathrm{~m}$ stem height, $2 \mathrm{~m}$ canopy spread across the row, $1.5 \mathrm{~m}$ spread within the row, and $1.0 \mathrm{~m}$ layer (thickness). The central leader trees had a conical shape, with the same stem height and the same canopy spread at the base as the horizontal canopy. The height of the fruiting mantle of the leader was $2 \mathrm{~m}$ and the height of the tree top was $2.7 \mathrm{~m}$. In 2015, the total leaf area was measured on four representative trees of each training system. All the leaves were stripped from the trees in August. The leaves were measured in the laboratory using an Area Measurement System (Delta-T Devices LTD, Burwell Cambridge, England). Leaf area index (LAI) was calculated as the ratio of the total leaf area on a tree to the ground area allocated for tree canopy. Cumulative yield was recorded in years 2012-2015 and presented in kilograms per tree.

The sunlight entering tree canopies was measured in 2015 with a Delta-T Tube solarimeter type TSL. The measurements were taken above and within tree canopies, at the end of July, only on sunny days, before midday between 11 am and 12 noon. Light distribution within tree canopies was measured on the same days along the rows, on three horizontal levels above the ground, for leader trees at 1.0, 1.5, and $2.0 \mathrm{~m}$; for horizontal canopies at 1.0 , 1.2 , and $1.4 \mathrm{~m}$. On each level, eight measurements were taken with the tube solarimeter that provided up to 240 readings of light spots. Light transmitted to the ground was measured on the same days as the light within the trees, across the alleyway. The measurements were performed on the ground, at intervals of $0.2 \mathrm{~m}$, contributing to 600 readings of the light transmitted to the ground. To obtain the value of light interception, it was calculated as the difference between the incoming light recorded above tree canopies, and the light transmitted to the ground level. The results were expressed as a percentage of sunlight within the canopy in relation to the irradiation above the orchard.

The results were statistically elaborated using an analysis of variance, followed by means separation using the Duncan multiple-range t-test at $\mathrm{p}=0.05$.

\section{RESULTS AND DISCUSSION}

Tree canopies achieved the required form, size, and accepted fruiting ability within 5 years from planting. The trees trained to a central leader 
were characterized by more regular summer growth than the trees trellised horizontally. Trellising required bending shoots to the horizontal position, and this treatment induced very strong growth at the shoot base and reduced growth at the shoot apex according to geotropic phenomenon (Mullins 1965). After 3 years, the differences in shoot growth pattern gradually ceased. The trees trained to the horizontal position grew less vigorously than the trees trained to the leader form. Significant differences in tree growth, expressed by TCSA, were clearly evident in 2015 (Table 1). The trees trained to the horizontal canopy also had a lower TCSA when spaced at $1 \mathrm{~m}$ in the row than at $1.5 \mathrm{~m}$. Summer shoot growth in 2015 was also weaker in the horizontally trained trees than in the leader trained trees (Table $1)$. Weaker growth of densely planted trees in comparison with trees planted at larger distances has been proved in numerous trials with apple (Mika et al. 1987, Mika \& Piskor 1997) and plum trees (Mika et al. 1998). The weaker growth at dense planting is the result of increased tree competition for space, sunlight, nutrients, and water. Restricting canopy size by training and pruning may bring similar results because of diminished leaf area.

Mechanical fruit harvesting of any tree species requires adaptation of plantations to harvesting technology. One must accept that the new technology may decrease the yield because of a certain percentage of fruit retained on the trees after harvesting

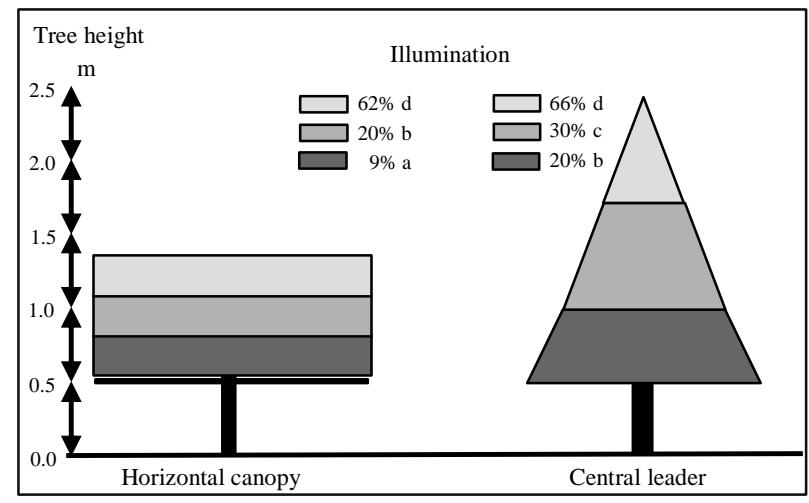

Fig. 1. Percentage of light distribution in three horizontal layers of horizontal canopy and central leader (means with the same letter are not significantly different at $\mathrm{p}=0.05$ according to Duncan's test) or lost on the ground. An acceptable level is about $5 \%$, with some fruit species, up to $10 \%$ (Castro-Garcia et al. 2012). In our trial, the trees trained to the horizontal canopy produced only $50 \%$ of the yield obtained from the leader trained trees (Table 1). The main reason for such a drastic reduction in yield is the small volume of the horizontal canopy (Table 1), nearly a half when compared with a central leader tree. This is proved by fruit load (kilogram of fruits per cubic meter of canopy), which was not the same for both training systems. The productivity index of leader trees was significantly higher than horizontal trees (Table 1). The other factor responsible for crop reduction could be unsuitable conditions for sunlight interception and distribution in the horizontal orchard architecture. Comparison of light interception, transmission, and distribution is presented in Fig. 2 and Table 2. The leader trees had canopies more dispersed in space, thus the light distribution was more even (Fig. 1). In all the parts of tree canopy, light intensity did not fall below the critical value of $20 \%$ when compared to the level of irradiation above tree canopy. By contrast, the horizontal canopy was compact. The measurements showed that at the canopy base, light intensities were very low, below 9\% what reduced photosynthesis and could increase fruit abscission (Jackson et al. 1977). This was most likely the reason why in the horizontal canopy system excessive fruit abscission was observed after fruit set in June.

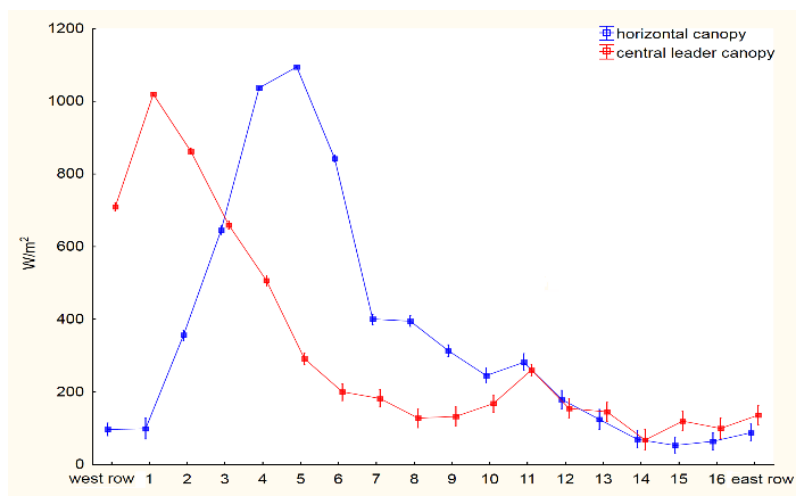

Fig. 2. Light transmission measured across $\mathrm{N}-\mathrm{S}$ oriented alleyway, from west row to east row at incident light above trees at $1200 \mathrm{~W} \mathrm{~m}^{-2}$ (vertical bars represent $\mathrm{SE}$ of the mean) 
Table 1. Effect of spacing and training system on cumulative yield of, three volume, TCSA, total shoot growth, productivity, and load indices of 'Elena' plum cultivar in two training systems

\begin{tabular}{|c|c|c|c|c|c|c|c|}
\hline Treatment & $\begin{array}{l}\text { Spacing } \\
\text { (m) }\end{array}$ & $\begin{array}{c}\text { Cumulative } \\
\text { yield } \\
2012-2015 \\
\left(\mathrm{~kg} \cdot \text { tree }^{-1}\right)\end{array}$ & $\begin{array}{c}\text { Tree } \\
\text { volume } \\
\left(\mathrm{m}^{3}\right)\end{array}$ & $\begin{array}{c}\mathrm{TCSA}^{* *} \\
2015 \\
\left(\mathrm{~cm}^{2}\right)\end{array}$ & $\begin{array}{l}\text { Total shoot } \\
\text { growth } \\
2015 \\
\text { (m) }\end{array}$ & $\begin{array}{c}\text { Productivity } \\
\text { index } \\
2015 \\
\left(\mathrm{~kg} \cdot \mathrm{cm}^{-2} \text { of the }\right. \\
\text { trunk })\end{array}$ & $\begin{array}{l}\text { Load Index } \\
2015 \\
\left(\mathrm{~kg} \cdot \mathrm{m}^{-3} \text { of can- }\right. \\
\text { opy volume })\end{array}$ \\
\hline Horizontal & $4 \times 1.0$ & $30.6( \pm 2.95) \mathrm{a}^{*}$ & 2.0 & $70.9( \pm 0.71) \mathrm{a}$ & $12.0( \pm 1.10) \mathrm{a}$ & $0.43( \pm 0.01) \mathrm{a}$ & $15.3( \pm 1.47) \mathrm{c}$ \\
\hline canopy & $4 \times 1.5$ & $32.6( \pm 3.04) \mathrm{a}$ & 3.0 & $85.5( \pm 0.40) b$ & $13.0( \pm 1.10) \mathrm{a}$ & $0.38( \pm 0.00) \mathrm{a}$ & $10.9( \pm 1.00) \mathrm{a}$ \\
\hline Central & $4 \times 1.5$ & $60.0( \pm 6.64) b$ & 5.7 & $102.8( \pm 1.61) \mathrm{c}$ & $16.0( \pm 1.10) b$ & $0.58( \pm 0.03) b$ & $10.5( \pm 1.17) \mathrm{a}$ \\
\hline leader tree & $4 \times 2.0$ & $72.3( \pm 5.60) \mathrm{c}$ & 6.2 & $110.6( \pm 0.84) \mathrm{c}$ & $17.0( \pm 1.10) b$ & $0.65( \pm 0.02) b$ & $11.7( \pm 0.90) b$ \\
\hline
\end{tabular}

*Means in columns with the same letter are not significantly different at $\mathrm{p}=0.05$ according to Duncan's test

** Trunk cross-sectional area

Table 2. Total leaf area, leaf area index, and light interception of 'Elena' plum in two training systems

\begin{tabular}{cccccc}
\hline Treatment & $\begin{array}{c}\text { Spacing } \\
(\mathrm{m})\end{array}$ & $\begin{array}{c}\text { Leaf area } \\
\left(\mathrm{m}^{2} \cdot \mathrm{tre}^{-1}\right)\end{array}$ & $\begin{array}{c}\text { Ground area under } \\
\text { canopy } \\
\left(\mathrm{m}^{2}\right)\end{array}$ & $\begin{array}{c}\text { Leaf area index } \\
(\mathrm{LAI})\end{array}$ & $\begin{array}{c}\text { Light interception } \\
(\%)\end{array}$ \\
\hline \multirow{2}{*}{ Horizontal canopy } & $4 \times 1.0$ & $10.2( \pm 1.0) \mathrm{a} *$ & 2.0 & 5.1 & $66.0( \pm 0.86) \mathrm{a}$ \\
\hline \multirow{2}{*}{ Central leader tree } & $4 \times 1.5$ & $13.5( \pm 1.0) \mathrm{ab}$ & 3.0 & 4.5 & $63.3( \pm 0.86) \mathrm{a}$ \\
\hline
\end{tabular}

*Means in columns with the same letter are not significantly different at $p=0.05$ according to Duncan's test

The differences in leaf area disclosed a pattern similar to the variations in tree volume and yield (Table 2). Trees with a higher canopy volume had the greatest leaf area. The leaf area index (LAI), calculated as the projection of total leaf area to the ground area below the canopy, was high. Its value (4.5-5.7) was similar to that found in a very intensive well-cropping apple orchard reported by Palmer (1989), Mika et al. (2002), and Buler and Mika (2004). The differences in LAI between the two training systems were negligible. This means that all the trees had similar conditions for photosynthesis concerning LAI (Table 2). Light transmission at a given hour (Fig. 2) showed a different pattern within the two training systems, but, generally, it was nearly the same. Light interception calculated as the proportion of incoming light to the light retained in tree canopy was not altered much by the two training systems (Table 2).

In conclusion, the authors state that horizontal canopy did not appear to be beneficial for high pro- duction of plum trees grown for mechanical harvesting in continuous motion. The canopy plane should be rather divided into two planes stretched along the row and inclined at a certain angle to the horizontal, similar to that in the "V" training system (Buler \& Mika 2009). Such an architecture of tree canopy will increase the canopy volume and improve sunlight penetration and distribution.

\section{CONCLUSIONS}

1. Light distribution is more optimal in the central leader than in the horizontal canopy systems.

2. The low volume of the horizontal canopy restricts its productivity.

\section{REFERENCES}

Buler Z., Mika A. 2004. Evaluation of the 'Mikado' tree training system versus the spindle form in apple trees. Journal of Fruit and Ornamental Plant Research 12: 49-60. 
Buler Z., Mika A. 2009. The influence of canopy architecture on light interception and distribution in 'Sampion' apple trees. Journal of Fruit and Ornamental Plant Research 17(2): 45-52.

Castro-García S., Blanco-Roldán G.L., Jiménez-Jiménez F., Muñoz-Tejada R., Gil-Ribes J.A. 2012. Table olive fruit and tree suitability to mechanical harvesting methods. International Conference of agricultural engineering CIGR-AgEng, 8-12 July, Valencia, Spain, pp. C2271.

Dunn J.S., Stolp M. 1981. Apple production for mechanical harvesting on the Lincoln canopy system. Extension Bulletin 10, New Zealand Agricultural Engineering Institute, $20 \mathrm{p}$.

Jackson J.E. 1970. Aspects of light climate within apple orchards. Journal of Applied Ecology 7: 207-216. DOI: $10.2307 / 2401373$.

Jackson J.E., Palmer J.W., Perring M.A., Sharples R.O. 1977. Effects of shade on the growth and cropping of apple trees. III. Effects on fruit growth, chemical composition and quality at harvest and after storage. Journal of Horticultural Science 52: 267-282. DOI: 10.1080/00221589.1977.11514755.

Mika A., Buler Z. 2015. Modifying apple spindle trees to improve fruit quality. Acta Scientiarum Polonorum Hortorum Cultus 14(3): 13-24.

Mika A., Piskor E. 1997. Growth and cropping of dwarf 'Jonagold' ('Jonica') apple trees planted at the density ranged from 2,000 to 10,000 per ha and trained as slender spindle, super spindle and $\mathrm{V}$ system. Acta Horticulturae 451(2): 473-478. DOI: 10.17660/ActaHortic.1997.451.54.

Mika A., Buler Z., Chlebowska D. 1998. The effect of training systems and planting density on growth and fruiting of plum trees grafted on two rootstocks. Acta Horticulturae 478: 107-112. DOI: 10.17660/ActaHortic.1998.478.16.

Mika A., Buler Z., Treder W. 2003. Optymalizacja nasłonecznienia i jakości owoców w sadzie intensywnym. Folia Horticulturae Suplement 2: 159-161.
Mika A., Buler Z., Treder W., Sopyła C. 2002. Relationship between fruit distribution within 'Jonagold' apple canopy, fruit quality and illumination. Journal of Fruit and Ornamental Plant Research 10: 7584.

Mika A., Słowik K., Piątkowski M. 1987. Wyniki badań nad uprawą jabłoni karłowych i półkarłowych sadzonych w dużym zagęszczeniu. Prace Instytutu Sadownictwa i Kwiaciarstwa, seria C, 1-4: 107108. [in Polish]

Mika A., Treder W., Buler Z. 2001. The effect of apple tree form on light interception, yielding and apple quality. Zeszyty Naukowe Instytutu Sadownictwa i Kwiaciarstwa 9: 49-55.

Mika A., Buler Z., Rabcewicz J., Białkowski P., Konopacka D. 2015. Suitability of plum and prune cultivars, grown in a high density planting system, for mechanical harvesting with a canopy contact, straddle harvester. Journal of Horticultural Research 23(2): 69-81. DOI: 10.2478/johr-2015-0017.

Mika A., Buler Z., Rabcewicz J., Białkowski P., Konopacka D. 2016. Horizontal canopy for plums mechanically harvested in continuous motion. Acta Scientiarum Polonorum Hortorum Cultus 15(6): 49-59.

Mullins M.G. 1965. The gravitational responses of young apple trees. Journal of Horticultural Science 40(3): 237-247. DOI: 10.1080/00221589.1965.11514136.

Palmer J.W. 1989. The effects of row orientation, tree height, time of year and latitude on light interception and distribution in model apple hedgerow canopies. Journal of Horticultural Science 64(2): 137145. DOI: 10.1080/14620316.1989.11515937.

Palmer J.W., Avery D.J., Wertheim S.J. 1992. Effect of apple tree spacing and summer pruning on leaf area distribution and light interception. Scientia Horticulturae 52: 303-312. DOI: 10.1016/03044238(92)90031-7.

Wagenmakers P.S. 1995. Light relations in orchard systems. Thesis Wageningen. CIP-Gegevens Koninklijke Bibliotheek, Hague, Netherlands, 149 p. 